\title{
Modernization of tax structure in Kosovo
}

\section{Remzi Smajli, PhD Cand.}

\author{
Prishtina - Republik of Kosova \\ e-mail: remzismaji@gmail.com
}

Tel +37744 145771

\begin{abstract}
An advantage in stabile economic balance in different countries is undoubtedly the form of fiscal system. Transformation towards modernization of the tax administration can undoubtedly bring favor the development of the economy with special emphasis on small business and middle. Fundamental changes that must occur in the tax structure redistribution of the tax burden and broaden the tax base. However leaders in this area requires special attention because this hypothesis is quite challenging because of the possible consequences. The main directions should have the right tax policy orientation; change in structure between direct and indirect taxes and tax structure right from the central or local level decentralization of tax power. Efficient functioning of the tax administration services and providing suitable conditions for fulfillment by taxpayers is the challenge of the tax system in Kosovo. One of the prerequisites of the efficiency of the tax system, in addition to organizational activities is the provision of modern information system, on which the tax administration of Kosovo should be on the cutting edge. This will simultaneously be the topic of discussion in my next paper for the Conference
\end{abstract}

Keywords: system, tax, change, economy, modernization.

\section{Introduction}

Public revenues and state departments with particular emphasis on budgets in different countries continuously face the difficulties of taxes collection, however in majority of the cases quite harsh methods have been applied for tax compliance towards taxpayers. This problem is acute in my country the Republic of Kosovo. Although in our practice so far have been used different types of taxes and methodologies as well as of the tax collection - public revenues, followed by difficulties, problems and none-willingness of taxpayers for tax payment.

Moreover, besides central, regional, municipal and local government authority, many institutions have their rules and regulations to pursue their objectives aiming their budget accomplishment whereby raising further obstacles for businesses and other tax payers, especially for newly established companies.

In the context of tax payment difficulties, the willingness to pay in one hand and the state budget accomplishment according to their needs, which are increasingly in different directions, the necessary conditions for taxpayers to enable settlement of tax obligations in line with the applicable laws, gives us the grounded element for a professional advancement study level of the tax system.

In the following of this scientific work we have tried to research and treat scientifically the problems of the tax system and policies, on the development and functioning in various countries with special emphasis on the Republic of Kosovo by comparison with countries in the region and global range. Development of the finance is a very important and irreplaceable factor that advances the economic processes, in which it also confirms the state economical and financial potential, citizens and business potential, as well as financing of the economic, social and state activities. Whereas management policies, techniques, terms and harmonization with financing needs and demands of citizens and the state, it determines their effect.

It is well-known that the last decade tax reforms in the countries under transition from former planned economies to market economies, it appears as a notable laboratory in the drafting of tax policy and tax practices. This is particularly evident for those countries (such as Hungary, the Czech Republic, Poland, Slovenia and the Baltic states) that moved rapidly at the beginning of the transition for presentation of the comprehensive tax reform, based on a common objective for their entry into the EU. At the beginning of transition, these countries had a challenge to establish the new fiscal institutions and the market oriented towards new tax systems. (Luigi Bernardi, Mark WSChandler and Luca Gandullia, Tax Systems and Tax Reforms in New EU Members, page 1). 
Kosovo started later on this reform process as a result of status that use to have until after the war when it had started the transition associated with the support of the counties sustaining its new status. One of the most important changes it was the fiscal reform. (Angel Pere, Albana Hashorva, Tax System in Western Balkan Countries - Between Simplicity and Efficacy, page 81)

In all countries on the transition, now members of the EU, the tax reform process was significantly influenced by their histories. Instead of coping of the Western-style taxation systems, they followed an evolutionary approach that had associated them in drafting of the tax systems (Luigi Bernardi, Mark WSChandler and Luca Gandullia, Tax Systems and Tax Reforms in New EU Members, 3).

Kosovo since after the war it had an interim period under the United Nations Mission Administration known as UNMIK and due to that could not avoid the direct impact of preferences and practices of the countries from where the mission's representatives were coming from, whereby ignoring the fact that Kosovo it had a tax tradition and experience.

\section{Problem and Objectives of the Study}

There are no-real and certainly no-perfect conditions for taxpayers and businesses for an optimal level of the accomplishment on common interests between the two parties of the interest such as governments and taxpayers. There are no-unique rules for the treatment of taxpayers in the establishment of public revenue - taxes whereby not denied the recent efforts of the European Union to standardize the methods of Value Added Tax by the Sixth European Convention.

On the other hand, the new system requires new rules to play with the purpose for establishing of an equal environment for all governments that should provide the sufficient participants with equal criteria. Majority of countries still do not have sufficient rules to protect their fiscal environment or their countries or their financial interests against the illegal activities. In areas such as taxation, on the other hand, the legacy of the system it leads to the assignment of very high levels of taxes and contributions, and the possibility of complications as well as rules that are continually changing.

The purpose of my study is: Being persistently theoretical and pragmatic researcher of the field of taxation and in conformity with this permanently dealing with economic phenomenon of the taxation, compliance, collection, implications, it makes me along with the desire my intentions for future studies, and the research of a new tax and fiscal system, with new methodology of the action, which initially I would call it equivalent tax that implies replacing of the profit tax, which later with in depth-studies I will try to define to perfection. This new reformatting of the tax system that implies also application of new and modern methods in terms of meeting the maximal conditions for businesses and tax administrators, always aiming for practical application in my country and beyond, will be a challenge for me and next generations to come, with insistence to be a new methodology of gathering the interest of taxpayers and governments, for a satisfactory fulfillment of the mutual interests.

The influence of fiscal policy on state budgets and as well on economic development with special emphasis on business but also in other economic factors up to the level of GDP have always urged the researchers in the academic field as well as institutionally. Efforts have been made to understand what has been the impact of fiscal policy in terms of economic development whereby numerous analyses took place. To come to the accomplishment of the large budgetary revenue in one hand and economic growth on the other hand, Kosovo and the Balkan countries should have stimulating conditions for the economy as countries on the approach to EU at the same time should have the ability for satisfactory fulfillment of their budgets.

The needs for economic growth as well as higher public revenues, has challenged many researchers, has developed theories and raised many issues concerning perfection of fiscal policies, their management and expenditures.

\section{Developments in Kosovo Tax System}

The state has numerous duties, as well as powers and daily responsibilities, those duties and responsibilities are based in the Constitution, the legal system, rules and regulations, various administrative guidelines and other provisions in 
accordance with defined and regulated legal and political system. Public revenues can be defined as income in cash (monetary means) during one year, which are in the service of the state, the social communities for fulfillment (coverage) of the social needs (Komoni, Sabaudin, 1983, 468.)

The Republic of Kosovo is relatively a small country and located in Southeastern Europe. Kosovo it has a population of about 1.8 million inhabitants with 50.55 percent male and 49.5 percent female, with 163.2 inhabitants per square kilometer and average of 5.9 family members.

Kosovo it continues to face the challenges in economic and social aspects with high unemployment around $40 \%$, which it makes about $2 / 3$ of the active population (15-64) or about 1.2 million people. Unemployment is higher among female $40 \%$, while $28.1 \%$ male. Public and capital investments which in recent years 2010/2013 had a significant participation on the budget, there are indications to decline in favor of the welfare of citizens and raising the level of the economy and reduce unemployment

However, although since the beginning of the financial economic crisis in 2007, Kosovo's economy grew by an average $4.7 \%$ price increase over this period (on average) $3.8 \%$ has influenced the benefits of such growth economy not fully transmitted in real incomes of the population. Kosovo Budget has different growth trends:

The system of public financial management and tax system are not at the right level, so this system should be stable and in ensuring an adequate level of fiscal discipline. Recently results in fiscal discipline in the review as a result of the measures according to Stand-By Arrangement with the IMF.

However, budget management of risks and challenges still follow as:

- Failure to use sufficient information routinely under medium-term expenditure framework

- Deviation from planned levels of the expenditures

- Inadequate supervision of budget expenditures by public enterprises

European Union - EU 27 members, is a high tax area, with the overall average tax ratio of $38.4 \%$ of GDP (weighted average) in 2010 . This is more than $50 \%$ higher than in the US (24.8\% of GDP). During the period $2000-2010$ the total tax ratio decreased by 2.0 points. (These figures are based on tax Trends report in the European Union, edition of 2012, published by Eurostat. Series Eurostat "statistics explained" gives slightly higher rate due to using a different methodology. The overall tax ratio is calculated by Eurostat on the basis of a denominator (GDP values) that includes calculation of production by the informal sector. This explains why low ratio of total tax may occur due to low tax rates but also due to high tax evasion)

Within the EU changes in global tax levels between Member States are too high. In Denmark (47.6\%), Sweden (45.8\%) and Belgium (43.9\%) global tax burden is 60 to $75 \%$ higher than in Lithuania (27.1\%), Romania (27.2\%), Latvia (27.3\%) and Bulgaria (27.4\%). All new Member States of EU have a global tax ratio which is below the EU average. These major changes largely depend on social policy selections:

The needs of state of Kosovo and the level of tax administration also require numerous efforts towards the enhancement of performance in compliance with European standards and regulations.

As in all modern states, also in Kosovo, different types of taxes, fees, contributions and other fiscal instruments compose the tax system regulated by well system laws.

Tax instruments operate on the basis of tax rates that are in line with the rules, regulations and laws that have been approved.

The tax system began to operate from the beginning of 2000. The value added tax replaced the sales tax and a presumptive tax and the tax on hotel services. In September 2001, began to apply the property tax, while in 2002 the profit tax and income tax. Kosovo has made changes, respectively the reforms in the tax system which are enhanced. So far the biggest reforms to the system were made in 2005 while continued in 2008. 
Tax systems are based on three pillars: according to the type also tax distinguish: - Direct taxation which includes personal income tax, corporate income tax and other income and capital taxes (inheritance tax and gift's taxes); - Indirect Tax , including VAT, excise taxes, taxes on consumption, taxes on products (goods) and production;

In the Republic of Kosovo currently are functioning these taxes: personal income tax, corporation tax and value added tax. In the Republic of Kosovo collection of budget funds have been realized from the two institutions which are authorized to administer the funds, Customs and Tax Administration of Kosovo (TAK), while local taxes have been collected by municipalities (throughout cities)

Tax system is organized and managed by the Tax Administration of Kosovo established in 2000 with the growth and development according to the needs of the Kosovo budget and adjusting and approximating towards the path to the European Union.

The trend of tax revenues has been very encouraging in the first decade showing stagnation in the last five years.

\begin{tabular}{|c|c|c|c|}
\hline \multirow{2}{*}{ Type of tax } & \multicolumn{3}{|c|}{ Revenues according to years } \\
\hline & 2011 & 2012 & 2013 \\
\hline Presumptive Tax & 875,347 & 409,839 & 70,831 \\
\hline Profit tax & $1,805,885$ & 117,480 & 163,273 \\
\hline Value added tax & $122,327,310$ & $131,394,869$ & $149,184,989$ \\
\hline $\begin{array}{l}\text { Wage tax withheld at } \\
\text { source }\end{array}$ & $56,075,975$ & $60,752,691$ & $61,962,028$ \\
\hline Individual business tax & $23,689,318$ & $26,202,558$ & $28,309,705$ \\
\hline $\begin{array}{l}\text { Interest, rents, property } \\
\text { rights etc }\end{array}$ & $1,385,580$ & $1,648,728$ & $1,650,280$ \\
\hline Corporation tax & $54,963,748$ & $63,372,768$ & $64,110,827$ \\
\hline Total & $261,123,163$ & $283,898,932$ & $305,451,932$ \\
\hline
\end{tabular}

Besides taxes, the tax administration is the collecting agent of pension scheme in Kosovo under intergovernmental agreements and legal act.. The trend is presented in the graphic below. 


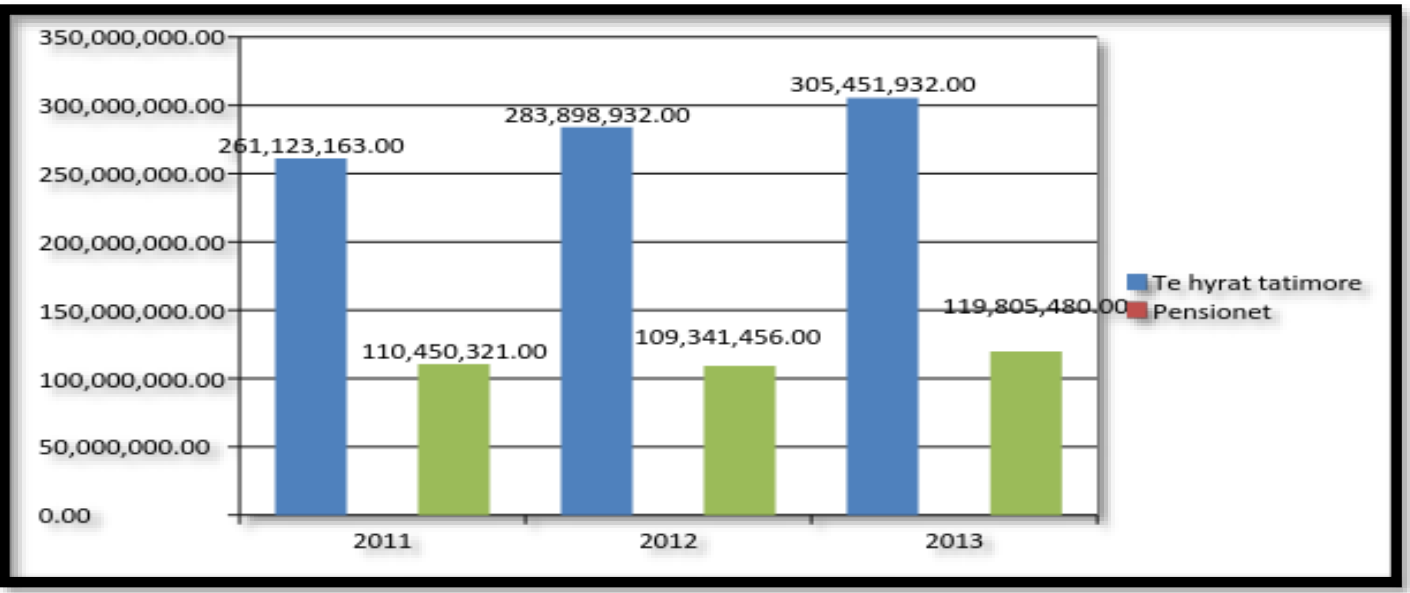

Taxpayer Information System is developed manually through workshops / seminars conducted across various cities with regional basis. Another option is provided through the distribution of tax brochures and leaflets and advertisement television campaigns on changes in legislation. The declaration of taxes from taxpayers is made through written forms of tax statements (declarations) in the front-offices across seven regions throughout Kosovo.

In recent years has entered into force also the module of electronic declaration for one type of the tax, tax withheld for personal income and a portion of VAT. This was a good action towards the beginning of the modernization of the tax system services towards offering better conditions for taxpayers. When it comes to the functioning of the tax administration itself it is well equipped with means of communication and data processing as well as with computers and respective servers. Also current administration possesses the Integrated Data Processing System under the license from Canada. A significant part of taxpayers have difficulties in declaring of their taxes because they are not equipped with respective computer means and tools, etc., to adapt themselves to the modern system of declarations.

Focalization system began in 2010 but it has faced the some difficulties in the selection of appropriate fiscal operators as well as the resistance of taxpayers to establish and place fiscal cash box devices, whereby businesses justified themselves on the grounds of the high cost for establishing these fiscal devices.

\section{Conclusions}

On the basis of the information gathered show that the tax administration in Kosovo has the duty to collect the revenues that enable the funding of public expenditure needs such as security, health education to social programs. This system of tax collection has made efforts in creating an environment in a way that you add the fulfillment of tax obligations by business and other tax groups. However, Kosovo is not creating a desirable tax system.

Among the priorities of this administration was to facilitate the process of fulfilling the administrative process easier, providing the guidelines etc. Tax administration has so far enabled to furnish taxpayers with brochures, leaflets and appropriate forms of taxes we physically last three years we electronically for some types of taxes.

The level of tax fulfillment compared with tax potential is still far from being realized, until when we compare ourselves with countries in the region and the EU, Kosovo, my country is far from optimal performance in the creation of the budget even though we have a good adaptation of legislation. 
The level of technological adaptation has started but is being developed at low rates. Taxpayers are not yet equipped with fiscal and the same does not have sufficient conditions for computer and technology provide sufficient. The tax administration has already begun the application of the system on-line declarations.

\section{Recommendations:}

Government and subordinate tax system should be more committed to the creation of appropriate conditions for taxpayers to meet their tax obligations, not only to assess their real tax base, equal treatment of taxpayers, but also in providing techni- conditions technological moderate. This means providing on-line services for the declaration and payment of taxes from taxpayers office at any time within the legal limits specified. The tax system should provide information to ensure taxpayers for their statements, broaden the tax base and increase revenues from taxes

Basic recommendations for the development, establishment and modernization of the tax system in the Republic of Kosovo and elsewhere in the region would be:

- Increase communication with the public and the taxpayer

- Develop technical capacities with contemporary level of technology

- Provide basic data of taxpayers.

- Increasing state taxpayer reports the level of reciprocity of interest.

- Provision of services on-line declarations

- Removal of disclosure forms, modification and reporting of acquisitions

- Provide ongoing explanations for taxpayers, including public rulings, individual, different answers, through physical copies, or e-mail, through the media, etc. •

- Provision of services to taxpayers, through the Call Center;

- Provide direct line to warn the public about cases of tax evasion and other bad occurrences.

Tax Administration as an agency authorized to collect taxes in addition to the regular work, routine and special inspections should provide guidance, explanations and individual public through the regular line electronic, through the media. Provide training and other activities for taxpayers.

\section{References:}

[1] Angel Pere, Albana Hashorva, Tax System in Western Balkan Countries - Between Simplicity and Advanced Stages Of Baldness,

[2] Ask.rks-gov.net

[3] Eurostat "statistics explained" gives slightly higher rate due to using a different methodology.

[4] Komoni Sabaudin, Finance, Prishtina 2008

[5] Luigi Bernardi, Mark WSChandler and Luca Gandullia, Tax Systems and Tax Reforms in New EU Members,

[6] Martinez-Vasquez Jorge, McNab Robert (1997), Tax Reform in Transition Countries: Experience and Lessons, International Studies Program, ËP 97 - 6, July

[7] Rosen \& Gayer, Financë Publike, 2010 UET Press

[8] www.atk-ks.org 